\title{
Sporadic Creutzfeldt-Jakob Disease with Autoimmune Encephalitis Antibody Positivity
}

\section{Oto-İmmün Ensefalit Antikor Pozitifliği Ille Seyreden Sporadik Creutzfeldt-Jakob Olgusu}

(1) Boran Can Saraçoğlu, ${ }^{1}$ Eren Gözke, ${ }^{2}$ Esma Kobak Tur ${ }^{2}$

\begin{abstract}
A wide spectrum of inflammatory and degenerative diseases including autoimmune encephalitis or paraneoplastic encephalitis (PNE) and sporadic Creutzfeldt-Jakob disease (sCJD) can be related to rapidly progressive cognitive decline. This report describes a patient with rapidly progressive dementia, myoclonus, and cerebellar findings with anti-Ma2/Ta antibody positivity who was diagnosed as probable SCJD. A 63-year-old female patient presented with progressive cognitive impairment, involuntary movements, and impaired walking and speech. Her symptoms worsened within weeks. An electrocardiogram revealed irregular, moderate, and high amplitude slow wave activity in both hemispheres with marked sharp wave discharges in the frontotemporal regions. Cranial diffusionweighted magnetic resonance imaging was performed and revealed bilateral hyperintensity on the nucleus caudatus and globus pallidus with frontal cortical ribboning. Testing yielded a negative result for the 14-3-3 protein in cerebrospinal fluid and a positive result for the anti-Ma2/Ta antibody. Intravenous immunoglobulin therapy was provided; however, the patient deteriorated and died. SCJD is a rare neurodegenerative disease with an unknown etiology. It is a fatal disease with no known effective treatment. Clinical signs are cerebellar dysfunction, epileptic disturbances, visual signs, and pyramidal/extrapyramidal findings. These symptoms may be non-specific and diagnosis can be challenging for clinicians. Autoimmune encephalitis, PNE, and SCJD may mimic each other and must be considered during the diagnostic process. When clinical suspicion arises, treatable etiologies of rapid cognitive decline should not be ignored and must be addressed to avoid a poor outcome.
\end{abstract}

Keywords: Auto-immune encephalitis; anti-Ma2/Ta antibody; creutzfeldt-Jakob disease.

\section{ÖZET}

Received: 13.07 .2019 Accepted: 22.07.2019

Correspondence: Dr. Boran Can Saraçoğlu. Şanlıurfa Mehmet Akif Inan Eğitim ve Araştırma Hastanesi, Sağlık Bilimleri Üniversitesi Nöroloji Bölümü, Şanlıurfa, Turkey Phone: +905362841088 e-mail: bcansaracoglu@gmail.com OPEN ACCESS (c) 00
Hızla ilerleyen kognitif bozukluk, oto-immün/paraneoplastik ensefalit (PNE) ve sporadik Creutzfeldt-Jakob hastalığı (sCJD) dahil olmak üzere geniş bir inflamatuar ve dejeneratif hastalık spektrumuna bağlı olabilir. Bu yazıda olası sCJD tanısı alan, anti-Ma2/Ta antikor pozitifliği ile hızlı ilerleyen demans, miyoklonus ve serebellar bulguları olan bir hasta sunmaktayız. 63 yaşında kadın hasta, hızlı ilerleyen bilişsel bozukluk, istemsiz hareketler, yürüme ve konuşma bozukluğu nedeniyle kliniğimize başvurdu. Belirtiler haftalar içinde hızlı ilerleme gösterdi. Hastanın EEG'sinde her iki yarım küre üzerinde frontotemporal bölgelerde belirgin keskin dalga deşarjı bulunan düzensiz, orta ve yüksek genlikli yavaş dalga aktivitesi saptandı. Kraniyal MRG yapıldı ve DWI frontal kortikal şeritlenme ile bilateral nükleus kaudatus ve globus pallidusta hiperintensite görüldü. BOS 14-3-3 protein sonuçları negatif çıktı ve Anti Ma2/Ta antikoru pozitif olarak bulundu. İntravenöz immünoglobulin tedavisine rağmen hasta kötüleşti ve öldü. sCJD, etiyolojisi belirlenemeyen nadir görülen bir nörodejeneratif hastalıktır. Bilinen etkili bir tedavisi olmayan ölümcül bir hastalıktır. Klinik bulgular serebellar disfonksiyon, epileptik bozukluklar, görsel bulgular ve piramidal/ekstrapiramidal bulgulardır. Bu semptomlar non-spesifiktir ve klinisyenler için tanı zor olabilir. Paraneoplastik ensefalit benzer belirtiler ile prezente olur ve tanı sürecinde göz önünde bulundurulması gerekir. Otoimmün/paraneoplastik ensefalit ve SCJD birbirlerini taklit edebilir ve klinik şüphe halinde, hızlı bilişsel gerilemenin tedavi edilebilir etiyolojileri göz ardı edilmemeli ve kötü sonuçları önlemek için tedavi edilmelidir.

Anahtar sözcükler: Anti Ma2/Ta antikoru; Creutzfeldt-Jakob hastalığl; oto-immün ensefalit. 
R apidly progressive dementia has a wide spectrum of inflammatory and degenerative diseases including autoimmune/paraneoplastic encephalitis (PNE) and sporadic Creutzfeldt-Jakob disease (sCJD). Both diseases may present with extrapyramidal symptoms, psychiatric problems and seizures accompanying cognitive impairment. CJD is a prion disease with no known treatment. It's usually presented with progressive dementia as well as myoclonus, parkinsonism and ataxia. Diagnosis is often based on clinical signs but can be supported by EEG findings (periodic sharp wave complexes), cranial MRI signs (T2 hyperintensity of basal ganglia, thalamus and cortex) and increased CSF 14-3-3 protein levels. ${ }^{[1]}$

There have been reported cases of PNE and SCJD mimicking each other and auto-immune encephalitis antibodies can be positive in as high as $\% 5$ in some series. ${ }^{[2-6]}$ With similar clinical and laboratory findings it is important for clinicians to differ CJD from treatable mimics.

We demonstrate a patient with rapidly progressive dementia, myoclonus and cerebellar findings with anti-Ma2/Ta antibody positivity who was diagnosed as probable CJD. While there are cases with anti-CASPR2, LGI-1, NMDAR and aquaporin4 positivity were reported3, there were no cases with anti-Ma2/Ta antibody positivity in literature.

\section{Case Report}

A 63-year-old female patient was admitted to our clinic due to progressive cognitive impairment, involuntary movements, impaired walking and speech. Patient was completely healthy until 2 months ago when her husband realized intermittent disorientation in time and space, confusion and disorganized behavior. Patient also complained involuntary jerk like movements ofherarms. She had trouble walking on her own and fell frequently. Her symptoms worsened within weeks, involuntary jerks were more frequent and especially prominent during sleep. She had trouble maintaining her daily activities and often complaint of forgetfulness. She was diagnosed with early dementia at another neurology clinic and referred to our clinic.

At the time of examination patient was disoriented to time and space, could recognize her close family members only. There was significant impairment in visuospatial abilities, short term memory and executive functions. A mini mental test was performed and she scored 15/30. Cranial nerves were intact. There were no motor or sensual deficit. Finger to nose test was abnormal bilaterally and dysmetria was noted. The patient suffered of impaired gait and truncal ataxia was present. During examination bilateral upper extremity myoclonus was observed. Left pupil was deformed, right pupil was spherical and light reflex was positive. Babinski was bilaterally negative. There was no rigidity and muscle tonus was normal.

EEG showed irregular, moderate and high amplitude slow wave activity on both hemispheres with marked sharp wave discharges in the frontotemporal regions. The patient was started on valproic acid $20 \mathrm{mg} / \mathrm{kg} /$ day. Cranial MRI was performed and DWI sections showed bilateral hyperintensity on nucleus caudatus and globus pallidus with mild frontal cortical ribboning (Fig. 1). Patient's routine biochemistry results including B12, TSH and cholesterol panel was within the normal range.

The primary investigation of cerebrospinal fluid revealed no leukocytes and CSF biochemistry including total protein was normal. Auto-immune encephalitis antibodies, paraneoplastic encephalitis antibodies and protein 14-3-3 was included in the work-up.

Meanwhile patients clinical condition deteriorated, patient became somnolent, myoclonic jerks increased. Valproate dosage was increased to $40 \mathrm{mg} / \mathrm{kg} /$ day. Anti Ma2/Ta antibody was revealed as positive. Patient was started on intravenous immunoglobulin $0.4 \mathrm{gr} / \mathrm{kg} /$ day for 5 days with diagnosis of paraneoplastic encephalitis. Considering possible malignancy thoracic-abdominal CT was performed with no abnormalities found. Thyroid US detected 3 isoechoicheterogeneous solitary nodules, biggest one measuring $13 \times 12$ $\mathrm{mm}$ in size. One of them showed increased vascularization on both shell and core. Her TSH, T3 and T4 levels were within the normal range however fine needle aspiration biopsy was per-

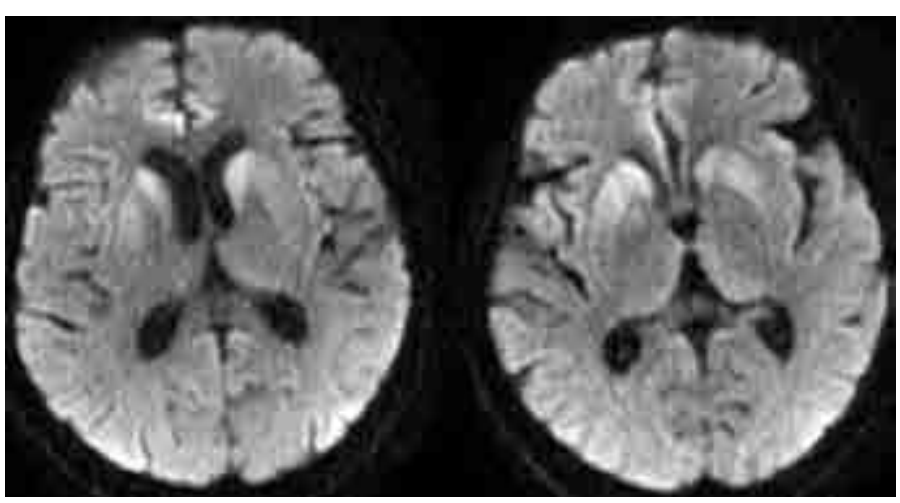

Figure 1. MRI images demonstrate hyperintensity of nucleus caudatus and globus pallidus with mild frontal cortical ribboning. 
formed due to high clinical suspicion. Mammography scan and full body PET-CT was planned but couldn't be performed due to patient's poor clinical condition.

In spite of IVIG treatment patient deteriorated and was transferred to neurological intensive care unit. CSF 14-3-3 protein results came back negative. Thyroid biopsy results showed hyperplastic nodule. Patient's family refused mechanical intubation. Two days later patient entered cardiopulmonary arrest and died. An autopsy was planned but patient's family did not give consent.

\section{Discussion}

Our patient presented with progressive cognitive decline as well as cerebellar dysfunction, myoclonus and gait instability. Subacute progression of these findings suggests many neurodegenerative diseases including but not limited to CJD and PNE.

SCJD is a rare neurodegenerative disease whose etiology is unidentified. It's a mortal disease with no known effective treatment. Clinical signs are cerebellar dysfunction, epileptic disturbances, visual signs and pyramidal/extrapyramidal findings. These findings are all non-specific and diagnosis could be very challenging for clinicians. Diagnosis is supported by EEG findings and cranial MR studies. EEG may show periodic sharp wave complexes or non-specific epileptic activity.

Cranial MRI can show hyperintensity of basal ganglia, thalamus, cortex and white matter on T2 sequences and cortical hyperintensity (ribboning sign) on DWI. CSF analysis for protein 14-3-3 and S100 also supports the diagnosis but are not mandatory. Since there is no definitive treatment for CJD, anti-epileptics and supportive treatment are mostly administered. Majority of patients die within 12 months of diagnosis.

PNE may present with similar signs which must be considered during diagnostic process. Anti Ma2/Ta antibodies were positive in our case, which is associated limbic encephalitis with memory impairment, seizures, extrapyramidal signs, eye movement abnormalities and sleep disturbances. It's often associated with testicular cancer and lung cancer, rarely with other malignancies. Neurologic symptoms may develop months before tumor diagnosis. Neurological presentation is wide; short term memory deficits, confusion, seizures, diencephalic dysfunction, ocular paralysis, dysarthria and dysphagia are common. ${ }^{[7]}$

Cranial MRI often reveals bilateral or unilateral medial tem- poral lobe abnormalities also hippocampi, hypothalamus, thalamus, midbrain and pons may be affected. CSF analysis is usually unrevealing, pleocytosis and increased protein concentration might be detected. ${ }^{[7]}$

Treatment for Ma2 paraneoplastic syndrome aims to neutralize inflammation caused by autoimmune response. Clinician should investigate for malignancy and treat primary tumor if found. Pharmacologic treatment includes corticosteroids, intravenous immunoglobulin, cyclophosphamide and azathioprine. Plasma exchange therapy may be useful but risk/benefit ratio must be considered. ${ }^{[8]}$

Our patients clinical, electrophysiological and MRI findings was fulfilling DCD's diagnostic criteria of probable sCJD. Auto-immune and paraneoplastic limbic encephalitis were also investigated during the diagnostic process and antiMa2/TA antibodies were found positive. Since diagnosis was unclear at that time and paraneoplastic encephalitis was a treatable cause, IVIG therapy was administrated but no clinical improvement was observed. We searched for a possible malignancy, there was no gynecological or thoracic tumor found yet we could not perform full body PET-CT.

\section{Conclusion}

Our final prognosis was SCJD with incidental anti-Ma2/Ta antibody positivity. Cases of autoimmune/paraneoplastic encephalitis and CJD mimicking each other was reported in literature ${ }^{[2-6]}$ but there were no reported cases of CJD and anti-Ma2/Ta antibody positivity. Whether antibody production due to prion induced immunoreaction or low sensitivity of these tests is the cause remains unknown.

Although this presented case had no response to intravenous immunoglobulin treatment, if clinical suspicion arise treatable etiologies of rapid cognitive decline should not be ignored and treated to avoid poor outcome.

\section{Disclosures}

Informed consent: Written informed consent was obtained from the patient for the publication of the case report and the accompanying images.

Peer-review: Externally peer-reviewed.

Conflict of Interest: None declared.

Authorship Contributions: Concept - B.C.S., E.G., E.K.T.; Design - B.C.S., E.G., E.K.T.; Supervision - B.C.S., E.G., E.K.T.; Materials - B.C.S., E.G., E.K.T.; Data collection \&/or processing - B.C.S., E.G., E.K.T.; Analysis and/or interpretation - B.C.S., E.G., E.K.T.; Literature search - B.C.S., E.G., E.K.T.; Writing B.C.S., E.G., E.K.T.; Critical review - B.C.S., E.G., E.K.T. 


\section{References}

1. Perry DC, Geschwind MD. Thorough work-up and new diagnostic criteria needed for CJD. Nat Rev Neurol 2011;7:479-80.

2. Zuhorn F, Hübenthal A, Rogalewski A, Dogan Onugoren M, Glatzel M, Bien CG, et al. Creutzfeldt-Jakob disease mimicking autoimmune encephalitis with CASPR2 antibodies. BMC Neurol 2014;14:227.

3. Rossi M, Mead S, Collinge J, Rudge P, Vincent A. Neuronal antibodies in patients with suspected or confirmedsporadic Creutzfeldt-Jakob disease. J Neurol Neurosurg Psychiatry 2015;86:692-4.

4. Geschwind MD, Tan KM, Lennon VA, Barajas RF Jr, Haman A, Klein CJ, et al. Voltage-gated potassium channel autoimmunity mimickingcreutzfeldt-jakob disease. Arch Neurol 2008;65:1341-6.

5. Grau-Rivera O, Sánchez-Valle R, Saiz A, Molinuevo JL, Bernabé R, Munteis E. Determination of neuronal antibodies in suspected and definiteCreutzfeldt-Jakob disease. JAMA Neurol 2014;7:71-8.

6. Chen Y, Xing XW, Zhang JT, Wang RX, Zhao W, Tan QC. Autoimmune encephalitis mimicking sporadic Creutzfeldt-Jakob disease: A retrospective study. J Neuroimmunol 2016;295-296:1-8.

7. Dalmau J, Graus F, Villarejo A, Posner JB, Blumenthal D, Thiessen B. Clinical analysis of anti-Ma2-associated encephalitis. Brain 2004;127:1831-44.

8. Kraker J. Treatment of anti-Ma2/Ta paraneoplastic syndrome. Curr Treat Options Neurol 2009;11:46-51. 